\title{
What price academic freedom?
}

\author{
The British government now has its Education Reform Act. Academics and their leaders should stay \\ alert until the government's intended uses of its powers are made clear.
}

ACADEMICs, like farmers, are an ungrateful and complaining lot. That, at least, must be the opinion of the British government, which last week carried its Education Reform Bill through the British parliament more or less intact. For the grumbling continues among academics even though the government has conceded on a number of important if symbolic issues - "academic freedom" has a legal definition, the Universities Funding Council will be able to offer advice to the government as well as to obey such directions as are handed down and, more important, these directions will be, in principle at least, open to scrutiny and debate. Why, with all this conceded, are academics still still grumbling?

The concessions are significant, and a considerable achievement for the Committee of Vice-Chancellors and Principals, which organized the campaign against the bill. The reason why discontent persists is mostly that the Education Reform Bill has brought about such a radical change of the rules that British academic life will never be the same again. That it should be necessary to define academic freedom in a legal statute gives the show away. The essence of the change that has been brought about is that British universities have ceased to be independent autonomous self-governing institutions, but have become dependent on the state not merely for funds but for direction. Many of the new-fangled instruments of public administration which the present government has recently devised, known as 'trading funds' or 'agencies', will enjoy more freedom than the run-of-themill British university.

It is not far-fetched to compare what has happened in Britain with what happened to the University of Malta, then the oldest university in the British Commonwealth, in the 1970s. The then Prime Minister of Malta, Mr Dom Mintoff, got it into his head that the university, by being selective and concerned with academic objectives, was elitist and unproductive. In such a small community, it was therefore natural that the university should be required to change its way of doing business. Knowing they had no right to resist, but only that of contrary persuasion, the university authorities fell in with Mintoff's more moderate proposals, weakening still further their capacity to mount effective resistance against his more malign intentions. By 1978, the university found certain of its courses being transferred to Malta's only other institution of higher education, the polytechnic in Valetta. Soon afterwards, the university was defunct.

While Mintoff and the present British government are poles apart on politics, their opinions of universities have one crucial element in common: each considers that universities by effeteness have failed society. The government of Malta in Mintoff's time believed that its single university had failed to propagate egalitarianism, the British government believes its larger university system should have made Britain more prosperous much sooner. By decreeing in the 1970 s that the government of Malta knew best how and where the university's courses should be taught, Mintoff was not necessarily going much further than the British government's plan that the Universities Funding Council should issue directions to universities in general and in particular about the balance of their teaching effort.

Some will protest that university systems as dependent on the state for funds as the British are always vulnerable, but that is an exaggeration. On mainland Europe, all university systems are state-financed and even state-governed, but academics are not as much threatened as under the Education Reform Act, as it has become. In West Germany, the responsibility of the Länder governments for higher education means that universities are at the centre of regional pride and aspiration. In France, despite the status of most academics as public employees, there is enough general respect for the independence of the academic life for the ground rules to have been virtually unchanged for decades, the upheavals of 1968 notwithstanding.

Britain's boast of the benefits of its distinctive means of laundering public money intended for university support now seems distinctly hollow. Originally, there was a University Grants Commission dependent directly on the Treasury which channelled funds towards the universities, largely on its own responsibility. Then tidy-mindedness suggests that the commission should become a committee, dependent on the Department of Education. That was in the early 1960 s, a period of rapid expansion in British higher education buoyed up by economic optimism. Then followed the longer period in which ambitions were lowered and budgets were constrained, matched meticulously against the needs of schools and of vocational education. The universities would have been better able to defend themselves against the events of this decade if they had not squandered so many of their political friendships in the previous decade, but they had no obvious reason to fear that the present government's animus against academic life would declare itself in the arbitrary 10 per cent plus cut in university budgets decreed at the end of 1980.

British and other academics know too well what has happened to British universities since then. As at the University of Malta in the late $1970 \mathrm{~s}$, the system has been weakened and demoralized to the point at which a push will send it reeling. What tends to be forgotten is that the much smaller university system immediately after the Second World War was in many ways much stronger than its successors have now become. Nostalgia is a poor guide to action now, because the circumstances are different, but the past should not entirely be forgotten.

Take, for example, the University of Manchester in the early 1950 s, with a student body half its present size. Within a few years of the Second World War, this institution, already distinguished for its historical studies by the presence of Lewis Namier, had built an innovative radioastronomy observatory (Jodrell Bank), had discovered strange particles in cosmic rays, had founded palaeomagnetism and built a digital computer that could have been the foundation of an industry now flourishing mostly elsewhere. Yet Manchester, if unusual, was by no means unique. And academics were broadly speaking as free as the air. They rarely complained that they had to work like dogs, but they were paid appallingly.

No purpose can be served by hoping that those happy times will spontaneously return, or that they would seem happy if they did. Things have changed. The participation rate in higher education has multiplied, in Britain, three times, and there is every reason for hoping that, in the national interest, it will become larger still. The best hope is that the government means what its spokesmen have been saying during the debates on the Education Reform Act, that it will not use the potentially malevolent powers the law now gives it. The vice-chancellors had better not disband their lobby until that is clear.

John Maddox 